\title{
Survei Kondisi Fisik Pencak Silat Persinas ASAD
}

\author{
Akbar Ridhwan*, Eko Hariyanto \\ Universitas Negeri Malang, Jl. Semarang No. 5 Malang, Jawa Timur, Indonesia \\ *Penulis korespondensi, Surel: ridhwanakbar174@gmail.com
}

Paper received: 3-5-2021; revised: 24-5-2021; accepted: 28-5-2021

\begin{abstract}
Abstrak
Kondisi fisik seorang atlet pencak silat sangat dibutuhkan untuk menunjang keterampilan teknik dasar serta prestasi atlet tersebut. Sama halnya dengan kegiatan pencak silat yang ada di lingkungan Pondok Pesantren Mahasiswa (PPM). Salah satu perguruan yang berada di lingkungan PPM ialah Persinas ASAD. Tujuan penelitian ini peneliti ingin mengetahui bagaimana kondisi fisik santri peserta kegiatan pencak silat di Pondok Pesantren Mahasiswa Baitul Jannah. Rancangan penelitian yang digunakan oleh peneliti adalah rancangan survei. Hasil survei tingkat kondisi fisik pencak silat di PPM BJ yaitu terdapat empat komponen yang berada pada kategori kurang atau rendah. Dalam hal ini peneliti menyimpulkan terdapat dua faktor yang paling mempengaruhi tingkat kondisi fisik yang rendah, yaitu 1) frekuensi latihan yang hanya dilakukan satu kali dalam satu minggu, dan 2) aktifitas fisik yang kurang dilakukan oleh para santri peserta kegiatan pencak silat Persinas ASAD di PPM BJ.
\end{abstract}

Kata kunci: kondisi fisik; pencak silat; pondok pesantren

\section{Pendahuluan}

Pencak silat adalah beladiri warisan budaya zaman dahulu bangsa Indonesia. Pencak silat perlu dijaga agar tidak hilang atau diakui oleh negara lain. Pencak silat adalah sistem beladiri yang diwariskan oleh nenek moyang sebagai budaya bangsa Indonesia sehingga perlu dilestarikan, dibina dan dikembangkan agar tidak hilang (Erwin, 2015) . Nilai-nilai luhur dalam pencak silat adalah nilai falsafah budi pekerti yang dijiwai oleh nilai-nilai falsafah Pancasila yang terdiri dari nilai teknis, atletis, estetis, dan etnis (Rohmah, 2012). Pencak silat adalah seni beladiri yang mempunyai kategori tanding, kategori tunggal, kategori ganda dan kategori regu.

Kondisi fisik merupakan salah salah unsur yang menjadi pencapaian prestasi dalam olahraga. komponen kondisi fisik diantaranya yaitu, kelincahan, kekuatan, kecepatan, daya tahan, dan keseimbangan. Sama halnya dengan pendapat (Budiwanto, 2012) menyatakan "komponen kondisi fisik terdiri dari kekuatan dan power, daya tahan otot, daya tahan kardiovaskular, kelincahan, kelentukan, kecepatan, keseimbangan, dan koordinasi". Beberapa komponen kondisi fisik dalam olahraga pencak silat diantaranya yaitu kelincahan, daya ledak otot, kecepatan dan daya tahan, karena komponen tersebut sangat dibutuhkan dalam bertanding.

Faktor yang memengaruhi daya ledak dalam tendangan taekwondo, meliputi: metode latihan, latihan dengan target fisik (Sudarsono, 2011). Latihan power tungkai berpengaruh terhadap keterampilan tendangan lurus pada olahraga pencak silat (Hasanudin, Muhtar, \& Dinangsit, 2018). Jenis kelamin dan berat badan juga memengaruhi kecepatan dalam olahraga (Sabatini, 2019). Faktor yang memengaruhi daya tahan jantung paru ialah aktivitas fisik. Semakin tinggi aktivitas fisik maka semakin baik daya tahan jantung paru. Aktivitas fisik merupakan variabel yang paling berhubungan dengan kesegaran jasmani pada anak sekolah, 
sedangkan jenis kelamin dan status gizi tidak menampakkan hubungan yang bermakna (Yoga, 2014). Faktor yang memengaruhi kekuatan ialah Latihan (Sudarsono, 2011).

Dalam beladiri pencak silat diwajibkan mempunyai kondisi fisik yang baik guna menghadapi benturan (body contact) saat latihan atau pun saat mengikuti pertandingan dengan lawan. Dalam penelitian menyatakan bahwa mencapai prestasi yang maksimal membutuhkan kondisi fisik yang baik adalah salah satu faktor yang menentukan pencapaian suatu prestasi olahraga (Ruslan, 2011). Manfaat dari kondisi fisik beladiri pencak silat di dalam latihan maupun saat mengikuti pertandingan mempunyai stamina yang baik. Jika kondisi fisik yang buruk maka akan sangat mempengaruhi di dalam teknik, mental, dan taktik yang mereka lakukan saat latihan maupun mengikuti pertandingan.

Boarding schools is one of Indonesia's oldest educational institutions, which became a central for pure religious activities (tafaqquh fi ad-di $>n>$ ) to spread Islam, maksudnya yaitu sekolah asrama adalah salah satu lembaga pendidikan tertua di Indonesia yang menjadi pusat keagamaan untuk menyebarkan Islam (Kusnadi et al., 2017). Pondok Pesantren Mahasiswa Baitul Jannah adalah pondok yang dinaungi oleh Lembaga Dakwah Islam Indonesia (LDII) dimana di beberapa kota dibangun Pondok-Pondok untuk Mahasiswa-Mahasiswi, dan pelajar. Hal ini bertujuan agar generasi penerus dapat menjadi anak yang sholeh dan sholehah yang mempunyai title/gelar sarjana. Oleh karena itu berbagai kota besar salah satunya kota Malang terdapat tiga Pondok Pesantren Mahasiswa yang dinaungi oleh Lembaga Dakwah Islam Indonesia (LDII) diantaranya yaitu, Pondok Pesantren Mahasiswa Baitul Jannah, Pondok Pesantren Mahasiswa Al-Kautsar, dan Pondok Pesantren Mahasiswa Nur Muhammad.

Olahraga pencak silat perguruan Persinas ASAD di PPM BJ digunakan sebagai sarana olahraga dan sebagai sarana prestasi olahraga bagi santri Pondok Pesantren Mahasiswa dan penjagaan diri dari bahaya disekitar. Selain itu kegiatan pencak silat juga sebagai sarana untuk mengikuti perlombaan-perlombaan yang diselenggarakan oleh perguruan Persinas ASAD dan kejuaraan lainnya. Berbagai kejuaraan yang diselenggarakan oleh perguruan Persinas ASAD sudah diikuti oleh santri putra diantaranya yaitu kejuaraan Daerah se-Kota Malang, Kejuaraan Provinsi Jawa Timur dan lain sebagainya.

Hasil observasi yang dilakukan peneliti kepada salah satu pelatih pencak silat Persinas ASAD di Pondok Pesantren Mahasiswa Baitul Jannah mengatakan bahwa, latihan pencak silat ini dilaksanakan seminggu sekali di hari Rabu pukul 15.30-17.00 WIB dengan jumlah peserta 30 orang. Mahasiswa yang mengikuti latihan pencak silat dibagi berdasarkan kategori yang diikutinya yaitu kategori tanding dan kategori tunggal (seni). Latihan pencak silat dalam kategori tanding yang diajarkan oleh pelatih berupa latihan teknik dasar dan latihan taktik yaitu, tendangan lurus, tendangan samping (sabit), pukulan depan, guntingan, sapuan, taktik serangan dan taktik bertahan.

Idealnya latihan yang diajarkan bukan hanya latihan teknik dasar saja, melainkan latihan kondisi fisik untuk menunjang dalam melakukan teknik dasar. Frekuensi latihan yang dilaksanakan tidak hanya 1 kali dalam 1 minggu, melainkan dilaksanakan minimal 3 kali dalam satu minggu. Hasil penelitian menyatakan bahwa dengan memanipulasi frekuensi Latihan 3 kali satu minggu dalam 6 minggu dapat meningkatkan komponen kondisi fisik (Saudini \& Sulistyorini, 2017). Padahal kondisi fisik seseorang itu sangat berpengaruh terhadap aktivitas yang dilakukan saat berolahraga. Hal ini berakibat pada pelatih pencak silat tidak mengetahui bagaimana cara melihat kondisi fisik para peserta kegiatan pencak silat Persinas ASAD di 
Pondok Pesantren Mahasiswa Baitul Jannah (PPM BJ). Jika kondisi fisik buruk maka akan mengganggu di dalam proses latihan maupun mengikuti pertandingan.

Berdasarkan paparan di atas dimana frekuensi latihan untuk menunjang dalam kondisi fisik seseorang harus melakukan latihan minimal 1-3 kali dalam 1 minggu untuk meningkatkan kebugaran atau kesehatan seseorang. Kenyataanya di Pondok Pesantren Mahasiswa Baitul Jannah (PPM BJ) dalam latihan pencak silat Persinas ASAD hanya melaksanakan latihan 1 kali dalam 1 minggu, dengan hanya latihan teknik dasar. Oleh karena itu, dalam penelitian ini peneliti berpendapat bahwa perlu dilakukan tes fisik untuk mengetahui kondisi fisik santri yang tinggal di Pondok Pesantren, serta perlu dikaji lebih lanjut dengan demikian penulis akan melakukan penelitian yang berjudul "Survei Kondisi Fisik Pencak Silat Persinas ASAD di Pondok Pesantren Mahasiswa Baitul Jannah".

\section{Metode}

Rancangan penelitian yang digunakan oleh peneliti adalah rancangan survei. Untuk menguatkan data, penelitian ini menggunakan jenis penelitian kuantitatif berupa tes karena data yang diperoleh dalam penelitian ini merupakan data angka. Teknik analisis data menggunakan teknik analisis deskriptif persentase.

Subjek penelitian ini adalah peserta kegiatan pencak silat Persinas ASAD di Pondok Pesantren Mahasiswa Baitul Jannah yang berjumlah 30 orang. Pengambilan subyek menggunakan teknik Total Sampling, yaitu pengambilan subyek menyeluruh dari keseluruhan total populasi. Subyek dalam penelitian ini berjumlah 23 siswa, dengan rincian 6 siswa lakilaki dan 8 siswa perempuan untuk kelompok usia 13-15 tahun. Sedangkan untuk kelompok usia 16-19 tahun dengan rincian 8 siswa laki-laki dan 1 orang siswa perempuan.

Instrumen tes yang digunakan adalah illinois agility run test untuk mengukur kecepatan, sergeant jump test untuk mengukur daya ledak, multistage fitness test untuk mengukur daya tahan, sprint 35 meter untuk mengukur kecepatan, dan push up test untuk mengukur kekuatan.

Setelah data dalam teknik pengukuran terkumpul, selanjutnya diklasifikasi dari setiap subyek menggunakan masing-masing norma setiap komponen tes kondisi fisik. Langkah selanjutnya yaitu menghitung persentase menggunakan rumus relative persentase.

\section{Hasil dan Pembahasan}

\subsection{Hasil}

Berdasarkan hasil analisis data deskriptif kuantitatif terhadap subyek penelitian setelah diperoleh data kasar dari pelaksanaan hasil tes, kemudian mengkonversikan data kasar dari masing-masing butir tes. Dengan menggunakan tabel norma yang sudah ada pada tiap tes komponen kondisi fisik peserta kegiatan pencak silat Persinas ASAD di Pondok Pesantren Mahasiswa Baitul Jannah dapat dikategorikan sebagai berikut 


\subsubsection{Komponen Kelincahan Illinois Agility Run Test}

Tabel 1. Persentase Komponen Kelincahan Illinois Agility Run Test

\begin{tabular}{ccccc}
\hline No & Interval & Kategori & Frekuensi & Persentase \\
\hline $\mathbf{1}$ & $<15.2$ detik & Excellent & 0 & 0 \\
$\mathbf{2}$ & $15.2-16.1$ detik & Above Average & 0 & 0 \\
$\mathbf{3}$ & $16.2-18.1$ detik & Average & 3 & 10 \\
$\mathbf{4}$ & $18.2-18.3$ detik & Below Average & 0 & 0 \\
$\mathbf{5}$ & $>18.3$ detik & Poor & 27 & 90 \\
& Jumlah & & 30 & $100 \%$ \\
\hline
\end{tabular}

\subsubsection{Komponen Daya Ledak Sergeant Jump Test}

Tabel 2. Persentase Komponen Daya Ledak Sergeant Jump Test

\begin{tabular}{ccccc}
\hline No & Interval & Kategori & Frekuensi & Persentase \\
\hline $\mathbf{1}$ & $>65 \mathrm{~cm}$ & Excellent & 1 & 3 \\
$\mathbf{2}$ & $50-65 \mathrm{~cm}$ & Above Average & 13 & 43 \\
$\mathbf{3}$ & $40-49 \mathrm{~cm}$ & Average & 7 & 23 \\
$\mathbf{4}$ & $30-39 \mathrm{~cm}$ & Below Average & 7 & 23 \\
$\mathbf{5}$ & $<30 \mathrm{~cm}$ & Poor & 2 & 7 \\
& Jumlah & & 30 & $100 \%$ \\
\hline
\end{tabular}

\subsubsection{Komponen Kecepatan Lari Sprint 35 meter}

Tabel 3. Persentase Komponen Kecepatan Lari Sprint 35 meter

\begin{tabular}{ccccc}
\hline No & Interval & Kategori & Frekuensi & Persentase \\
\hline $\mathbf{1}$ & $<4.80$ & Excellent & 7 & 23 \\
$\mathbf{2}$ & $4.8-5.09$ & Good & 1 & 3 \\
$\mathbf{3}$ & $5.10-5.29$ & Average & 2 & 7 \\
$\mathbf{4}$ & $5.30-5.60$ & Fair & 11 & 37 \\
$\mathbf{5}$ & $>5.60$ & Poor & 9 & 30 \\
& Jumlah & & 30 & $100 \%$ \\
\hline
\end{tabular}

\subsubsection{Komponen Daya Tahan Multistage Fitness Test}

Tabel 4. Persentase Komponen Daya Tahan Multistage Fitness Test

\begin{tabular}{ccccc}
\hline No & Interval & Kategori & Frekuensi & Persentase \\
\hline $\mathbf{1}$ & $>55.9$ & Superior & 0 & 0 \\
$\mathbf{2}$ & $51.0-55.9$ & Excellent & 0 & 0 \\
$\mathbf{3}$ & $45.2-50.9$ & Good & 1 & 3 \\
$\mathbf{4}$ & $38.4-45.1$ & Fair & 2 & 7 \\
$\mathbf{5}$ & $35.0-38.3$ & Poor & 5 & 17 \\
$\mathbf{6}$ & $<35.0$ & Very Poor & 22 & 73 \\
& Jumlah & & 30 & $100 \%$ \\
\hline
\end{tabular}




\subsubsection{Komponen Kekuatan Push Up}

Tabel 5. Persentase Komponen Kekuatan Push Up Test

\begin{tabular}{ccccc}
\hline No & Interval & Kategori & Frekuensi & Persentase \\
\hline $\mathbf{1}$ & $>70$ & Baik Sekali & 0 & 0 \\
$\mathbf{2}$ & $54-69$ & Baik & 0 & 0 \\
$\mathbf{3}$ & $38-53$ & Sedang & 3 & 10 \\
$\mathbf{4}$ & $22-37$ & Kurang & 27 & 90 \\
$\mathbf{5}$ & $<21$ & Kurang Sekali & 0 & 0 \\
& Jumlah & & 30 & $100 \%$ \\
\hline
\end{tabular}

Menurut hasil analisis data, ada beberapa komponen kondisi fisik yang paling banyak memiliki kategori rendah yaitu komponen kelincahan dengan persentase $90 \%$ pada kategori poor, komponen daya tahan sebesar 73\% pada kategori very poor, dan komponen kekuatan sebesar 90\% pada kategori kurang. Sedangkan untuk komponen daya ledak dan kecepatan paling banyak menunjukkan kategori sedang dan atau di atas rata-rata. Untuk komponen daya ledak memiliki persentase paling besar pada kategori above average sebesar $43 \%$ dan untuk komponen kecepatan kategori paling besar memiliki persentase $37 \%$ pada kategori fair.

\subsection{Pembahasan}

Hasil tes tentang komponen kondisi fisik peserta kegiatan pencak silat Persinas ASAD di Pondok Pesantren Mahasiswa yang menggunakan komponen tes kondisi fisik umur 16-19 tahun terdiri dari 5 butir tes komponen kondisi fisik, yaitu: (1) Ilinois Agility Run Test; (2) Sergeant Jump Test; (3) Lari Sprint 35 meter; (4) Multistage Fitness Test; (5) Push Up.

Kondisi fisik merupakan syarat penting bagi orang yang melakukan aktivitas olahraga. Kondisi fisik yang baik akan menunjang di dalam setiap melakukan olahraga seseorang. Kondisi fisik yang baik merupakan faktor yang harus dimiliki oleh setiap atlet terutama dalam memperoleh keterampilan teknik dan taktik. Selain itu dalam penelitian (Rohman, 2019) yang berjudul "Profil Kondisi Fisik Atlet PPLP Pencak Silat Jawa Timur" menyimpulkan bahwa kondisi fisik adalah kemampuan dasar yang harus dimiliki oleh atlet pencak silat dalam mendukung teknik, strategi, dan taktik dalam pertandingan.

Menurut hasil analisis data, ada beberapa komponen kondisi fisik yang paling banyak memiliki kategori rendah yaitu komponen kelincahan dengan persentase $90 \%$ pada kategori poor, komponen daya tahan sebesar $73 \%$ pada kategori very poor, dan komponen kekuatan sebesar $90 \%$ pada kategori kurang. Sedangkan untuk komponen daya ledak dan kecepatan paling banyak menunjukkan kategori sedang dan atau di atas rata-rata. Untuk komponen daya ledak memiliki persentase paling besar pada kategori above average sebesar $43 \%$ dan untuk komponen kecepatan kategori paling besar memiliki persentase $37 \%$ pada kategori fair.

Menurut peneliti ada beberapa faktor yang berpengaruh terhadap rendahnya kondisi fisik atlet pencak silat Persinas ASAD di PPM BJ, terutama dalam komponen daya tahan, kelincahan, dan kekuatan. Faktor-faktor yang mempengaruhi tiga komponen tersebut yaitu 


\subsubsection{Frekuensi Latihan}

Hasil penelitian menyatakan bahwa dengan memanipulasi frekuensi Latihan 3 kali satu minggu dalam 6 minggu dapat meningkatkan komponen kondisi fisik (Saudini \& Sulistyorini, 2017). Sejalan dengan hasil penelitian yang menyatakan bahwa dalam merencanakan suatu latihan perlu memperhatikan takaran latihan aerobik seperti frekuensi 3 kali satu minggu (Palar, Wongkar, \& Ticoalu, 2015). Hal ini berbeda dengan frekuensi latihan pencak silat yang ada di PPM BJ, jadwal latihan hanya dilakukan satu kali dalam satu minggu. Seharusnya frekuensi latihan yang baik untuk mendukung kondisi fisik dan prestasi atlet harus dilakukan minimal 1-3 kali dalam satu minggu.

\subsubsection{Aktivitas Fisik}

Hasil penelitian menunjukkan bahwa terdapat hubungan aktivitas fisik antara kelincahan dan daya ledak otot tungkai terhadap tendangan sabit (Rosmawati, Darni, 2019). Kelincahan penting saat atlet bertanding untuk melakukan serangan dan bertahan. Hasil penelitian menunjukkan adanya kontribusi yang signifikan antara kelincahan dengan kemampuan tendangan sabit (Dewi, 2014). Oleh karena itu hasil penelitian juga menunjukkan komponen kelincahan pada kondisi fisik pencak silat di PPM BJ menunjukkan pada kategori poor.

Hasil penelitian menunjukkan bahwa terdapat hubungan aktivitas fisik daya ledak otot tungkai terhadap kontribusi yang positif tendangan depan atlet pencak silat UKO UNP (Hardiansyah, 2016). Daya ledak berpengaruh dalam aktivitas pencak silat saat melakukan serangan kepada lawan. Sama halnya dengan hasil penelitian yang menunjukkan bahwa terdapat hubungan antara power otot tungkai dengan kemampuan tendangan lurus pencak silat (Anse, 2017). Oleh karena itu hasil penelitian juga menunjukkan komponen daya ledak pada kondisi fisik pencak silat di PPM BJ menunjukkan pada kategori above average.

Hasil penelitian menunjukkan bahwa terdapat hubungan yang signifikan antara kecepatan reaksi dengan kemampuan melakukan tendangan sabit pada beladiri pencak silat Siswa SMPN 3 Raha (Zulkifli \& Mongsidi, 2019). Kecepatan memberikan pengaruh terhadap kecepatan tendangan sabit pada atlet pencak silat Persaudaraan Setia Hati Terate (Tofikin, 2019). Hal ini berarti kecepatan sangat mempengaruhi atlet dalam melakukan serangan. Oleh karena itu hasil penelitian juga menunjukkan bahwa kondisi fisik pada komponen kecepatan di kegiatan pencak silat PPM BJ ini berada pada taraf fair.

Hasil penelitian menunjukkan adanya pengaruh latihan kekuatan otot lengan terhadap kemampuan servis atas bolavoli (Abdillah, Dkk, 2017). Dalam penelitian menunjukkan adanya pengaruh antara kekuatan otot lengan terhadap kemampuan smash pada cabang olahraga Bolavoli (Maifa, 2019). Hal ini berarti kekuatan otot lengan mempengaruhi pukulan atlet pada saat melakukan serangan. Oleh karena itu hasil penelitian juga menunjukkan bahwa kondisi fisik pada komponen kekuatan di kegiatan pencak silat PPM BJ ini berada pada taraf kurang.

Hasil penelitian menunjukkan terdapat hubungan positif antara aktivitas fisik dengan daya tahan jantung paru pada atlet pencak silat (Nurhayati, Goenawan, Farenia, Rasjad, \& Purba, 2019). Hal ini berarti semakin tinggi aktivitas fisik maka semakin baik daya tahan jantung paru. Aktivitas fisik termasuk salah satu faktor fisiologis yang mempengaruhi daya tahan cardiovascular (Sudiana, 2014). Pada kegiatan pencak silat di PPM BJ ini, para santri yang 
mengikuti kegiatan pencak silat masih aktif kuliah sehingga cenderung sedikit untuk melakukan aktifitas fisik di luar jadwal latihan yang hanya dilakukan dalam satu kali dalam satu minggu tersebut. Oleh karena itu hasil penelitian juga menunjukkan bahwa kondisi fisik pada komponen daya tahan di kegiatan pencak silat PPM BJ ini berada pada taraf rendah (very poor). Daya tahan yang baik dibutuhkan dalam mendukung komponen kondisi fisik pencak silat yang lain, seperti kecepatan, kekuatan, dan kelincahan. Jika daya tahan tubuh baik, maka seseorang cenderung lebih banyak melakukan latihan-latihan komponen kondisi fisik lainnya.

\section{Simpulan}

Dari lima komponen kondisi fisik di atas maka peneliti menyimpulkan bahwa terdapat empat komponen yang berada pada kategori kurang atau rendah, yaitu komponen kelincahan dengan persentase $90 \%$ pada kategori poor, komponen daya tahan sebesar $73 \%$ pada kategori very poor, dan komponen kekuatan sebesar 90\% pada kategori kurang. Sedangkan untuk komponen daya ledak dan kecepatan paling banyak menunjukkan kategori sedang dan atau di atas rata-rata. Dalam hal ini peneliti menyimpulkan terdapat tiga faktor yang paling memengaruhi tingkat kondisi fisik yang rendah, yaitu 1) frekuensi latihan yang hanya dilakukan satu kali dalam satu minggu, dan 2) aktifitas fisik yang kurang dilakukan oleh para santri peserta kegiatan pencak silat Persinas ASAD di PPM BJ.

\section{Daftar Rujukan}

Abdillah. (2017). Pengaruh Latihan Kekuatan Otot Lengan Terhadap Kemampuan Servis Atas Dalam Permainan Bolavoli Mahasiswa Putra. Jurnal Pendidikan Olahraga, 6(2), 96-103.

Anse, L. A. (2017). Hubungan Power Otot Tungkai Dengan Kemampuan Tendangan Lurus Pencak Silat Pada Club Perisai Putih Kabupaten Kolaka Timur. Jurnal Ilmu Keolahragaan, 16(1), 47-56.

Budiwanto, S. (2012). Metodelogi Latihan Olahraga. Malang: Penerbit Universitas Negeri Malang.

Dewi, A. K. (2014). Kontribusi kelincahan dan kecepatan terhadap tendangan sabit pada atlet pencak silat putra usia 12-14 tahun. Jurnal Ilmu Kesahatan Universitas Negeri Surabaya, 2 (2), 158-163.

Erwin, S, K. (2015). Pencak Silat. Yogyakarta: Pustaka Baru Press.

Hardiansyah, S. (2019). Kontribusi Daya Tahan Kekuatan Dan Daya Ledak Otot Tungkai Terhadap Kemampuan Tendangan Depan Atlet Pencak Silat Unit Kegiatan Olahraga UNP. Menssana, 1(2), 61-67.

Hasanudin, Muhtar, T., \& Dinar Dinangsit. (2018). Pengaruh Latihan Power Tungkai Terhadap Keterampilan Tendangan Lurus Pada Olahragara Pencak Silat. SporTIVE, 1(1), 321-330.

Kusnadi, E., Sobur, K., \& Aziz, A. (2017). in Between Islamic Boarding School: a Study of Al-Mubarok Al-Islam Within the Social Changes of Seberang Kota Jambi. Addin, 11(1), 101. https://doi.org/10.21043/addin.v11i1.1920

Maifa, S. (2019). Hubungan Antara Kekuatan Otot Lengan dan Daya Ledak Otot Tungkai dengan Kemampuan Smash dalam Permainan Bola Voli pada Mahasiswa Penjaskesrek Angkatan 2017/2018 STKIP Paris Berantai Kotabaru. Jurnal Ilmiah Pendidikan, 7(1), 122-129. https://doi.org/10.33659/cip.v7i1.126

Nur Rohmah, M. (2012). Pemanfaatan Nilai Luhur Pencak Silat Sebagai Upaya Pengembangan Karakter Melalui Pendidikan Jasmani. Prosiding Seminar Nasional, Program Pasca Sarjana UNY, Yogyakarta, 12 Mei.

Nurhayati, T., Goenawan, H., Farenia, R., Rasjad, A., \& Purba, A. (2019). Korelasi aktifitas fisik dan komposisi tubuh dengan daya tahan jantung paru. Jurnal Ilmu Faal Olahraga Indonesia, 1(2), 9-14.

Palar, C. M., Wongkar, D., \& Ticoalu, S. H. R. (2015). Manfaat Latihan Olahraga Aerobik Terhadap Kebugaran Fisik Manusia. Jurnal E-Biomedik, 3(1). https://doi.org/10.35790/ebm.3.1.2015.7127

Rohman, U. (2019). Profil Kondisi Fisik Atlet PPLP Pencak Silat Jawa Timur. Journal Physical Education, Health and Recreation, 3(2), 112-121.

Rosmawati, Darni, H. S. (2019). Hubungan Kelincahan dan Daya Ledak Otot Tungkai Terhadap Kecepatan Tendangan Sabit Atlet Pencak Silat Silaturahmi Kalumbuk Kecamatan Kuranji Kota Padang. Jurnal Menssana, 4(1), 44-52. https://doi.org/https://doi.org/10.24036/jm.v4i1.33 
Ruslan. (2011). Meningkatkan Kondisi Fisik Atlet Pusat Pendidikan dan Latihan Olahraga Pelajar (PPLP) di Provinsi Kalimantan Timur. Ilara, 11(2), 45-56. Retrieved from http://digilib.unm.ac.id/files/disk1/7/universitas negeri makassar-digilib-unm-ruslan-348-1-7.ruslac.pdf

Sabatini, D. (2019). FAKTOR-FAKTOR YANG MEMPENGARUHI KECEPATAN, KEKUATAN, DAN DAYA LEDAK TERHADAP TENDANGAN PADA ATLET TAEKWONDO. Jurnal Pendidikan Olahraga, 8(2), 85-95. https://doi.org/10.31571/jpo.v8i2.1120

Saudini, A. F., \& Sulistyorini. (2017). Pengaruh Latihan Squat Terhadap Peningkatan Power Otot Tungkai. Indonesia Performance Journal, 1(2), 71-75.

Sudarsono, S. (2011). Penyusunan Program Pelatihan Berbeban untuk Meningkatkan Kekuatan. Ilmiah SPIRIT, 11(3), 31-43. https://doi.org/10.31571/jpo.v8i2.1120

Sudiana, I. K. (2014). Peran Kebugaran Jasmani bagi Tubuh. Seminar Nasional FMIPA UNDIKSHA IV, 389-398. Retrieved

from https://ejournal.undiksha.ac.id/index.php/semnasmipa/article/download/10507/6718

Tofikin, T. (2019). Pengaruh Daya Ledak Otot Tungkai, Kecepatan Dan Kelincahan Terhadap Kecepatan Tendangan Sabit Pada Atlet Pencak Silat Persaudaraan Setia Hati Terate Di Kota Pekanbaru. Jurnal Pendidikan Rokania, IV(2), 209-219.

Yoga, A. H. (2014). Hubungan Jenis Kelamin, Aktifitas Fisik dan Status Gizi dengan Kesegaran Jasmani Anak Sekolah Dasar. Jurnal Kesmasindo, 7(1), 31-38.

Zulkifli, Z., \& Mongsidi, W. (2019). Hubungan Antara Kecepatan Reaksi Dengan Kemampuan Tendangan Sabit Beladiri Pencak Silat Pada Siswa Smpn 3 Raha. Jurnal Wahana Kajian Pendidikan, 3(2), 46-55. 